\title{
【症例報告】
}

\section{ハトムギ全粒熱水抽出エキス (CRD) 摂取 により根治した足底疮贅例 \\ Two Cases of Plantar Wart Successfully Cured by Intake of Coix-seed Reactive Derivatives (CRD)}

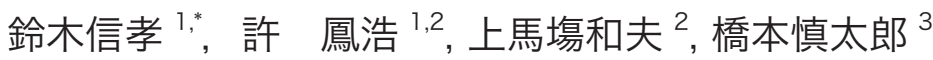 \\ Nobutaka SUZUKI ${ }^{1, *}$, Hoko KYO ${ }^{1,2}$, \\ Kazuo UEBABA ${ }^{2}$, Shintaro HASHIMOTO ${ }^{3}$ \\ 1 金沢大学大学院医薬保健学総合研究科 臨床研究開発補完代替医療学講座 \\ 2 医療法人ホスピィー・浦田クリニック \\ ${ }^{3}$ 大名町スキンクリニック
}

【要 旨】

ハトムギの外殼・薄皮・渋皮を含む全粒熱水 抽出エキス (CRD) の機能性を探求するため に, CRD 摂取が有用であった足底痕贅の 2 症例を報告した. 今後も,さらなる症例の集 積を試みる予定である.

$$
\text { 【キーワード】 }
$$

ハトムギ, Coix-seed Reactive Derivatives (CRD), 足底疮贅, 症例報告

\section{はじめに}

我々は，ハトムギの外殼・薄皮・渋皮の食効に着目 し, 酵素処理を組み合わせたハトムギ全粒熱水抽出物 (CRD:Coix-seed Reactive Derivatives) を研究開発した (日本国特許 第 3590042 号)。CRD の安全性や機能 性についてはこれまでいくつか報告してきた ${ }^{1-10)}$. 以前, $\mathrm{CRD}$ 摂取が奏功した難治性足底疮贅の一例を初めて報 告したが ${ }^{11)}$ ，今回新たに足底疮贅に有効だった 2 例を 経験したので追加報告する．2 症例とも 1 包中ハトムギ CRD エキス $2.2 \mathrm{~g}$ を含有する栄養補助食品(エリティス： 大木産業株式会社）を自由摂取した例である。なお，本 報告の写真はすべて本人もしくは家族が撮影したもので あり，本誌掲載にあたっては本人または保護者から同意 を得た。また，いずれの例にも副作用は認めなかった。
Case 18 歳小学生 女性 病名 足底疮䩀

既往歴に特記すべきことなし。1 年前から右足底部に疮 贅を認め, 徐々に大きくなったものの, とくに皮膚科の治 療は受けていなかった (Fig.1-a).エリティスを 1 包/日摂 取開始 6 週間後, 疮贅の周りは柔軟になってきた (Fig.1-b). 摂取 8 週間目には, 疙贅の中心部が黒色に変化し (Fig.1-c), 10 週目に疸贅は自然脱落し (Fig.1-d)，まもなく治癒し たので，エリティスは計 3 ケ月間摂取ののち中止した。 Fig. 1-e は, 摂取終了後 3 ケ月目の足底部写真である。なお, 現在, 摂取終了後, 1 年経過したが疮贅の再発はない.

Case 226 歳 女性 病名 足底疸贅

既往歴に特記すべきことなし。6 ケ月前より左足底部に 疮贅が出現し，そのまま経過を観察していた（Fig.2-a）. エリティスを 2 包/日摂取開始し，1 ケ月後の時点では疮 贅の大きさはほとんど変化しなかった（Fig.2-b).しかし， 摂取 2 ヶ月後からは著明に退縮し（Fig.2-c） (Fig.2-d), 捸 取 4 ヶ月後に消失した (Fig.2-e)。その後，再発は認めて いない.

\section{考 察}

足底疮贅は他の部位と異なり, 治療に苦慮することが ある。ふつう疮贅の治療としては, 液体窒素による凍結療 法が主流であるが，強い痛みを伴うことが問題である。ま た, 効果が不十分な場合も多く, 外科的手術や炭酸ガスレー ザーによる焼灼なども行われる ${ }^{12)}$ 。さらに漢方薬ヨクイニ ン（ハトムギ子実熱水抽出物）内服, 活性ビ夕ミン $\mathrm{D}_{3}$ 外用, 

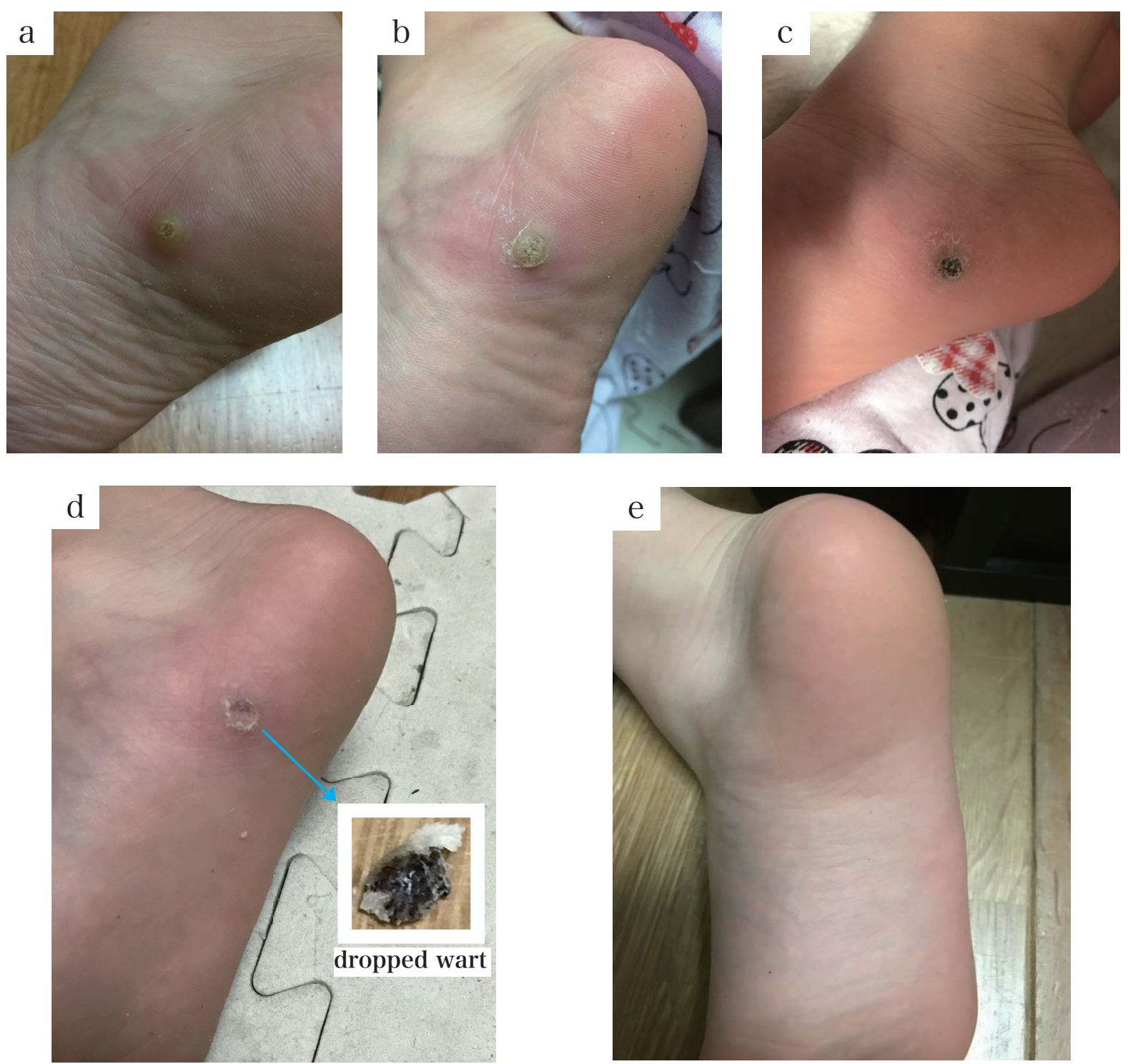

Fig. 1 Right plantar wart (8 years of age; female) CRD intake ; $2.2 \mathrm{~g} /$ day for 3 months

a: before intake b: 6 weeks later c: 8 weeks later d: 10 weeks later e: 6 months later ※ CRD: Coix-seed Reactive Derivatives

モノクロロ酢酸外用，グルタルアルデヒド外用，ブレオマ イシン局所注射なども行われるが ${ }^{12)}$ ，苦慮する例も少なく ない.

我々が最初に報告した難治性足底疮贅患者は，上記の各 種治療法に抵抗性であり，唯一 CRD が優れた抗疮贅作用 を示した例であった ${ }^{11)}$. CRD 摂取 2 ケ月後では，結節の 一部には縮小傾向がみられたものの全体的には病変に顕著 な変化は認められなかったが, 摂取 3 ケ月後になると, 結 節は著明に縮小し，一部剥離が認められ，4 月月後に結節 はすべて消失した ${ }^{11)}$.

今回の Case 1 は子供であったためか, 反応が大変よく, 摂取 10 週目に結節は自然脱落した。しかし, Case 2 は, やはり初回報告例 ${ }^{11)}$ と同じく，摂取 2 ヶ月目まではほと んど変化がなく，治癒には４ヶ月を要した。以上，今回の
2 症例は初発からの経過が長く,かつ他の治療法は全く行つ ていなかったので，CRD 摂取が極めて有効だった例と考 えた。今後，さらに足底疮贅の症例を集積し，CRDの有 用性を検証していく予定である。

\section{助成元}

なし

\section{利益相反}

本試験に用いたハトムギ全粒熱水抽出エキス CRD は著 者鈴木信孝らが設立した大学発ベンチャー企業 (株) CRD の研究開発食品である。 

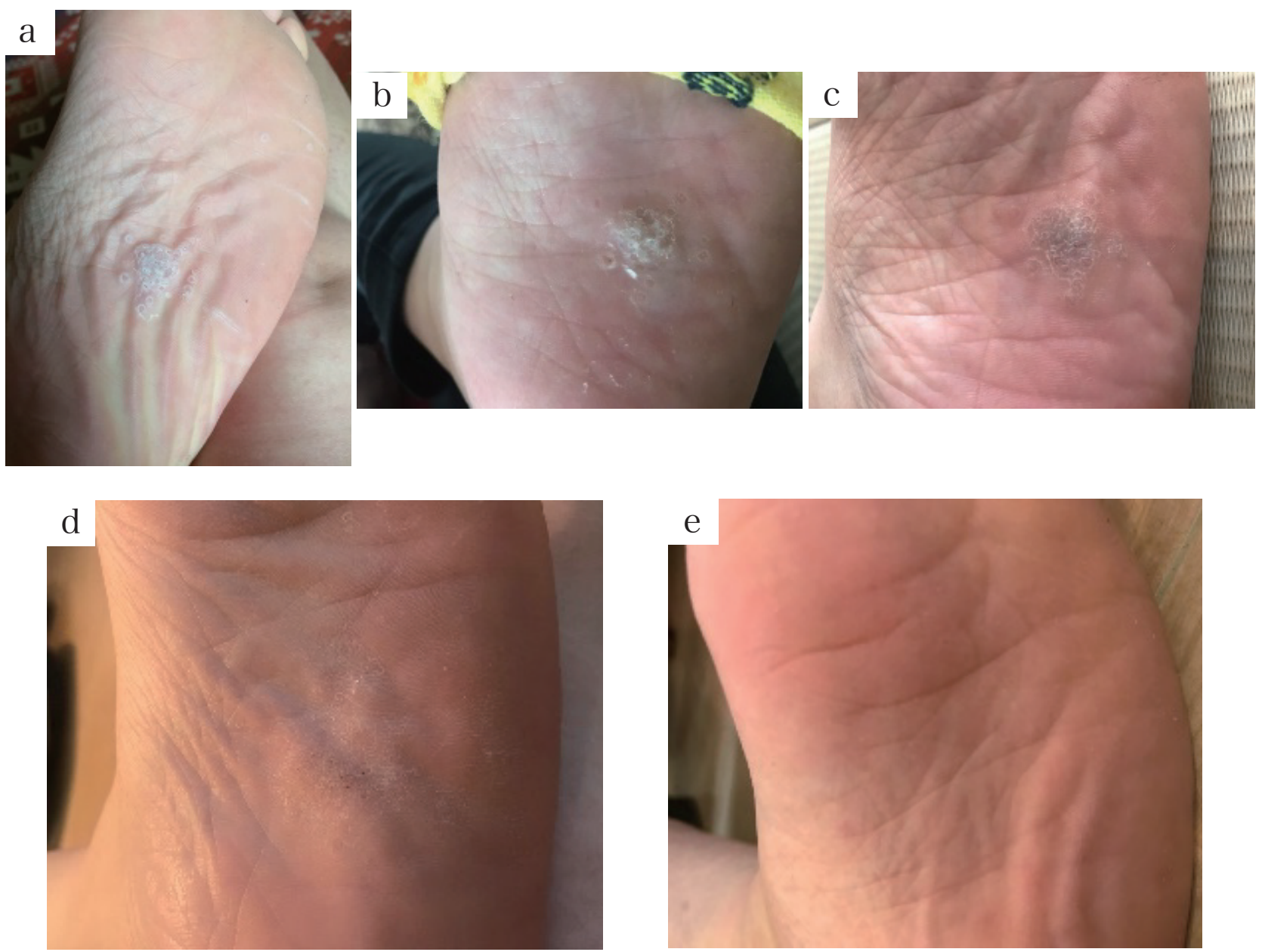

Fig. 2 Left plantar wart (26 years of age; female)

CRD intake; $4.4 \mathrm{~g} /$ day for 4 months

a: before intake b: 1 month later c: 2 months later d: 3 months later e: 4 months later

※ CRD: Coix-seed Reactive Derivatives

\section{参考文献}

1) Hayashi H, Ohta Y, Arai T, et al. Acute oral Toxicity test of hot water extract of Coix lacryma-jobi L. var. mayuen Stapf in rats. JJCAM. 2009;6(2):105-110.

2) Hayashi H, Arai T, Strong JM, et al. 28-day repeated dose oral toxicity test of Coix lacryma-jobi L. var. mayuen Stapf in rats. JJCAM. 2009;6(3):131-135.

3) 林浩孝，石橋範人，太田真弓ら。卡ムギ熱水抽出物の変 異原性試験。日本補完代替医療学会誌。2009;6(3):157162 .

4) 鈴木信孝.ハトムギの食品としての機能性と有用性。特産 種苗. 2009;3:20-24.

5) 鈴木信孝。ハトムギと健康体質．FOOD STYLE 21．2014; 18(6):57-61.

6) 鈴木信孝, 川島拓也, 許鳳浩ら. Coix-seed Reactive Derivatives (CRD) の皮膚色素沈着に与える影響に関する研究. 日本補 完代替医療学会誌. 2018;15(2):85-90.

7) 鈴木信孝, 許鳳浩. ハトムギ全粒熱水抽出エキス:事例研究.
日本補完代替医療学会誌．2018;15(2):127-132.

8) 鈴木信孝, 杉本勇人, 橋本慎太郎ら. Coix-seed Reactive Derivatives (CRD) 摂取が光老化皮膚の改善に有用であっ た事例報告。日本補完代替医療学会誌。2019;16(1):53-56.

9) 鈴木信孝, 橋本慎太郎, 許鳳浩ら. Coix-seed Reactive Derivatives (CRD) 摂取が難治性貨幣状湿疹の改善 に有用であった事例報告. 日本補完代替医療学会誌. 2019;16(1):61-65.

10）鈴木信孝, 許鳳浩, 上馬塲和夫ら.八トムギ全粒熱水抽出 エキス (Coix-seed Reactive Derivatives:CRD) 攝取が有用 であった尋常性痤瘡例：症例集積研究。日本補完代替医療 学会誌. 2019;16(2):119-126.

11) 鈴木信孝, 川島拓也, 許鳳浩ら. Coix-seed Reactive Derivatives (CRD) とビタミン剂の併用療法により根治し た難治性疮贅・コンジローマ症例. 日本補完代替医療学会誌. 2018;15(2):133-139.

12) 清水宏. 新しい皮膚科学. 第 3 版. 東京. 中山書店. 2018:495-496. 


\title{
ABSTRACT \\ Two Cases of Plantar Wart Successfully Cured by Intake of Coix-seed Reactive Derivatives (CRD)
}

\author{
Nobutaka SUZUKI ${ }^{1}$, Hoko KYO ${ }^{1,2}$, Kazuo UEBABA ${ }^{2}$, Shintaro HASHIMOTO ${ }^{3}$ \\ ${ }^{1}$ Department of Complementary and Alternative Medicine Clinical Research and Development, \\ Kanazawa University Graduate School of Medical Science \\ ${ }^{2}$ Urata Clinic, Hospy Medical Association \\ ${ }^{3}$ Daimyomachi skin Clinic
}

To clarify the functions of Coix-seed Reactive Derivatives(CRD), we observed 2 cases of plantar wart (case 1.8 years of age, female/ case 2. 26 years of age, female) successfully cured by intake of CRD for several months. Although CRD intake seemed to be effective in these cases, further studies are needed to define the optimal dose and duration.

Key words: Coix lacryma-jobi L. var. ma-yuen Stapf, Coix-seed Reactive Derivatives (CRD), plantar wart, case report 